\title{
California's privately owned oak woodlands: Owners, use, and management
}

\author{
LYNN HUNTSINGER AND LOUISE P. FORTMANN
}

\begin{abstract}
Social science research is an important tool for guiding development of education programs for owners of private rangelands. California oak woodland, a productive and extensive range type in California that is undergoing rapid changes in use and management, is the focus of this study. Results indicate that landowners with different property size differ demographically, make different uses of their land, and have distinctly different attitudes toward oak management and living in the oak woodland. Owners of smaller properties, on the increase in rural California, do not earn their living from their land, and will respond best to resource education programs that they believe will contribute to bettering the quality of life they seek by residing in the oak woodland. Owners of larger properties, the traditional clientele of advisory agencies, will more likely respond to programs that protect and enhance earnings from their property. Still, even a third of the owners of the largest (over 5,000 acres) properties eam the majority of their income from sources other than their lands. To be effective, range-oriented education programs and policies must track the changing composition of rural populations, and the changes in attitudes, needs, and interests that accompany demographic shifts.
\end{abstract}

Key Words: oaks (Quercus spp.), survey research, landowners, extension, private land use, policy, attitudes

Authors are assistant professor and professor, Department of Forestry and Resource Management, University of California at Berkeley 94720.

The authors wish to acknowledge James Bartolome and Paul Starrs for editorial assistance and technical advice, Pam Muick for her work during the early stages of the study and for giving us the benefit of her expertise in oak ecology, and Lee Wensel for his suggestions on data interpretation. This study was commissioned by University of California Cooperative Extension to guide the development of education programs for oak woodland landowners.

Manuscript accepted 21 June 1989.
California's oak woodlands produce about one third of the forage used by the state's range livestock industry, 4 to 5 million Animal Unit Months annually (Ewing et al. 1988) and harbor more wildlife than any other habitat type in California (Mayer et al. 1986). Since 1986 , these rangelands, of which $84 \%$ are privately owned (Ewing et al. 1988), have been the focus of a state-sponsored interagency cooperative education and research effort aimed at conserving oak woodland resources in the face of growing population pressure and changes in land use and management. The landowners who use and manage the oak woodlands and their associated resources are the subject of this survey research study.

The most productive rangelands in California are private land, where resource condition is strongly influenced by the needs and goals of the individual owner. These lands provide not only a livelihood to the landowner, but a variety of public goods, including wildlife habitat, watershed, and open space. Education programs are the primary tool used by advisory agencies such as the Soil Conservation Service or Agricultural Extension for reaching the owners and managers of private rangelands. Survey research can provide information necessary for the development of effective range management programs to meet the needs and interests of such target audiences.

Over the last decade, California privately owned oak woodlands have become a subject of concern to the public, to local and state policymakers, and to the range livestock industry. Landowners can profit from sales of oak firewood to growing rural and urban markets. Thinning and clearing oaks can raise forage production. But there are indications that in many cases, oak harvest may result in a permanent loss of oaks, due to an apparent lack of regenera- 
Table 1. Comparison of the weighted and actual sample: percent of owners, land and average property size.

\begin{tabular}{lccc}
\hline \hline & $\begin{array}{c}\text { Under } \\
200 \text { Acres } \\
\mathrm{N}=36^{1}\end{array}$ & $\begin{array}{c}200-5000 \\
\text { Acres } \\
\mathrm{N}=53^{1}\end{array}$ & $\begin{array}{c}\text { Over } \\
5000 \text { Acres } \\
\mathrm{N}=31^{1}\end{array}$ \\
\hline $\begin{array}{l}\text { Percent of sample (number of } \\
\text { owners) }\end{array}$ & 31.6 & 46.5 & 21.9 \\
$\begin{array}{l}\text { Percent of weighted sample } \\
\text { (number of owners) }\end{array}$ & 98.0 & 1.7 & .1 \\
$\begin{array}{l}\text { Percent of land in sample } \\
\text { Total land in sample: 792,509 }\end{array}$ & 0.3 & 11.5 & 88.2 \\
$\quad \begin{array}{l}\text { acres } \\
\text { Percent of land in weighted }\end{array}$ & 2,764 & 90,912 & 698,833 \\
$\quad \begin{array}{l}\text { sample } \\
\text { Average property size } \\
\quad \text { (weighted) }\end{array}$ & 28.6 & 42.1 & 29.2 \\
$\begin{array}{l}\text { Average property size (sample) } \\
\text { (1) }\end{array}$ & 10 & 867 & 14,667 \\
\hline
\end{tabular}

IN varies slightly with each question.

tion of several oak species (Sudworth 1908, Muick and Bartolome 1987). Between 1945 and 1973, hardwoods were removed from 890,000 acres of California rangeland, largely to increase forage production and for sale as firewood (Mayer et al. 1986). Since 1980 , oaks on another approximately 300,000 acres have been cut, mostly for residential and commercial development (Bolsinger 1988).

Assuming that most rangeland owners are alike, range management advisors have traditionally relied on education programs and practices that emphasize increased profits for livestock producers. This is a poor assumption for 2 reasons. First, numerous studies note that social factors, values, and attitudes, and not just profits strongly affect the decisions of range livestock producers (Grigsby 1976, Martin and Jefferies 1966, Shanks 1978, Smith and Martin 1972). Demographic characteristics, such as education level (South et al. 1965, Green and Blatner 1986); age (Romm et al. 1985, Green and Blatner 1986, Leveque 1984); and income (South et al. 1965, Romm et al. 1985, Leveque 1984), also strongly affect the use and management of resource lands. Other factors shown to affect landowner resource management are residence on the land (Ostrum 1985, Romm et al. 1985) and participation in working on the land by the owner (South et al. 1965, Leveque 1984, Green and Blatner 1986).

Second, as in many rural areas, the ownership of California oak woodlands since 1970 has shifted away from the traditional rangeland clientele, the livestock producer with ownership of or access to extensive property. The shift toward smaller rural land ownerships has been well documented nationwide (Healy and Short 1981, Healy 1985) as well as for California (Ewing et al. 1988). Size of property has been shown to influence resource management (Guillard 1982, Giordano 1978, Hefferman and Green 1986, Young 1985, Leveque 1984, South et al. 1965, Thompson and Jones 1981).

Serving the needs and interests of increasing numbers of new and different landowners is a challenge that advisory agencies face in developing successful education programs for rangeland owners. Yet, with the exception of a single survey of Tulare County livestock producers (McClaran and Bartolome 1985), oak woodland research at the time of this 1985 survey was almost exclusively biological in focus. While the body of information about the botanical and ecological characteristics of oak woodlands was substantial and increasing, little was known about the private landowners and managers who will determine the fate of the vast majority of California's oak woodlands.

This study examines differences in demographic characteristics, attitudes, values, and land uses associated with 3 different sizes of oak woodland rangeland landholdings and how these characteris- tics might affect owner receptivity to education programs and policy. First the demographic characteristics of owners are presented. Next, land use, attitudes, and values are described. Conclusions include recommendations for policymakers and advisory agencies.

\section{Study Area}

The 7.4 million acres of oak woodland (sometimes referred to as hardwood rangelands) (Ewing et al. 1988) intermix with valley annual grasslands at low elevations, and with montane forest at upper elevations. Characterized by an oak (Quercus spp.) overstory and annual grass (Bromus spp., Avena spp., Hordeum spp., Festuca spp., Vulpia spp., Medicago spp., Trifolium spp.) understory, they occupy coastal and valley foothills throughout most of the state in the Mediterranean climate zone (James 1966) from sea level to about 6,000 feet in elevation. Canopy cover varies from complete closure in the dense thickets found in canyons, to open savanna woodlands characteristic of foothill slopes. The type and its many variations are described thoroughly by Griffin (1977).

Cropland and urban development have constricted the lower bounds of the extent of rangeland oak species. Forest practices encouraging conversion from low-value hardwoods to high-value softwoods threaten oaks at the upper part of their range. But prior to the last 2 decades, foothill oak woodlands were generally considered marginal, unsuited to cultivation or forestry. Grazing has been the dominant use of the lands since the settlement of California (Burcham 1982, Farquhar 1966). These rangelands remain valuable wildlife habitat, producing the acorns that are a major food source for a wide variety of species. Migratory Sierran mule deer herds use the oak woodlands for winter range (Mayer et al. 1986). And for many of the state's citizens, the "majestic oak" has become an essential part of the California landscape.

\section{Methods}

In spring of 1985, after extensive pre-testing with selected landowners not part of the study sample, private owners of oak woodland throughout the state were surveyed by mail, using the stand-

Table 2. Characteristics of landowners: education, income, tenure, and memberships.

\begin{tabular}{|c|c|c|c|c|}
\hline & $\begin{array}{c}\% \\
\text { Owners } \\
\text { Under } \\
200 \text { Acres } \\
N=36^{1}\end{array}$ & $\begin{array}{c}\% \\
\text { Owners } \\
200-5000 \\
\text { Acres } \\
N=531\end{array}$ & $\begin{array}{c}\% \\
\text { Owners } \\
\text { Over } \\
5000 \\
\text { Acres } \\
\mathrm{N}=251\end{array}$ & $\begin{array}{l}\text { Estimated } \\
\text { \% Total } \\
\text { Acres } \\
\text { Wtd. } \\
\text { Sample }^{2}\end{array}$ \\
\hline College graduate 3 & $63.8^{2}$ & $43.2^{n}$ & $45.9^{\mathrm{a}}$ & 52.3 \\
\hline Under 46 years old & $30.6^{\mathrm{a}}$ & $26.0^{n}$ & $12.5^{\mathrm{a}}$ & 23.7 \\
\hline Income 75,000 and over & $2.7^{\mathrm{a}}$ & $11.8^{\mathrm{a}}$ & $29.2^{\mathrm{b}}$ & 18.1 \\
\hline $\begin{array}{l}\text { Member livestock association } \\
\text { or farm bureau } \\
\text { Land in family } 21 \text { years or }\end{array}$ & $24.2^{\mathrm{a}}$ & $64.7 b^{b}$ & $87.5^{\circ}$ & 56.1 \\
\hline $\begin{array}{l}\text { more } \\
\text { Major source of income: }\end{array}$ & $21.1^{\mathrm{A}}$ & $55.6^{\mathrm{b}}$ & $80.0^{b}$ & 52.8 \\
\hline ranching & $2.9^{\mathrm{a}}$ & $24.0^{\mathrm{b}}$ & $65.5^{\mathrm{c}}$ & 28.5 \\
\hline farming & $2.9^{n}$ & $8.0^{\circ}$ & $4.2^{\mathrm{a}}$ & 6.2 \\
\hline timber & $0.0^{\mathrm{a}}$ & $4.0^{\mathrm{a}}$ & $0.0^{\mathrm{a}}$ & 2.4 \\
\hline other & $94.3^{\mathrm{a}}$ & $64.0^{\mathrm{b}}$ & $33.3^{\mathrm{c}}$ & 63.3 \\
\hline Absentee owner & $33.3^{\mathrm{a}}$ & $34.5^{a}$ & $12.5^{\mathrm{a}}$ & 22.7 \\
\hline $\begin{array}{l}\text { Member wildlife or environ- } \\
\text { mental group } \\
\text { Had contact with an advisory } \\
\text { service about oaks, last five } \\
\text { years }\end{array}$ & $18.2^{\mathrm{a}}$ & $31.4^{\mathrm{a}}$ & $20.8^{n}$ & 24.6 \\
\hline
\end{tabular}

1N varies slightly with each question.

2Estimated percent of California oak woodland acres owned by landowners with the above characteristics or using the practices above on some or all of their land.

${ }^{3}$ Within rows, values without a common superscript are significantly different at $p<.05$, as determined by Chi-square analysis. 
ard technique described by Dillman (1979). An introductory letter and questionnaire is followed by a postcard reminder if a response is not received within 2 weeks. If this fails to produce a response, another letter and questionnaire follows, then a registered letter, and finally the potential respondent is telephoned. The objective is to achieve a high response rate. The greater the response rate, the less "self-selection" influences responses and hence the greater the representativeness of the sample.

Questionnaires were sent to the owners of land containing the Forest Inventory Assessment plots previously used to assess hardwood volume in California (Bolsinger 1988). The plots were established at the intersection points of a randomly established $11-\mathrm{k}^{2}$ grid overlaid on the state. Plots designated as "Hardwood Woodland Type" (USDA-Forest Service 1981) were selected for this study if an overstory of $10 \%$ or greater canopy cover was predominately Quercus spp. and the plot was on private land. By definition, these lands do not now, and show no evidence of ever having had, $10 \%$ or more cover of trees of industrial roundwood species and quality. Usable plots occurred in $\mathbf{3 8}$ of the state's $\mathbf{5 8}$ counties, at elevations ranging from 260 to 5,900 feet.

Usable questionnaires were returned by 126 of 166 eligible respondents for a response rate of $76 \%$. More than 792,509 acres were owned by the responding landowners, exceeding $10 \%$ of California's oak woodlands (Table 1). Landowners were asked about their demographic characteristics, attitudes, land tenure, land use, and management practices. Questions are condensed in Tables 2 through 4 .

The grid method used to establish Forest Inventory Plots means that larger properties have a greater probability of being selected for the sample (Wensel 1983). While this resulted in a sample with good representation of landowners of each property size, it means that responses about land use practices cannot be directly extrapolated to the oak woodland as a whole. For this reason, responses to each question were evaluated in 2 ways. First, contingency table analysis was used to make pairwise comparisons of responses of landowners in 3 property size categories. Property size categories
Table 3. Land use goals and oak harvest practices.

\begin{tabular}{|c|c|c|c|c|}
\hline & $\begin{array}{c}\% \\
\text { Owners } \\
\text { Under } \\
200 \text { Acres } \\
\text { N=36! }\end{array}$ & $\begin{array}{c}\% \\
\text { Owners } \\
200-5000 \\
\text { Acres } \\
N=53 !\end{array}$ & $\begin{array}{c}\% \\
\text { Owners } \\
\text { Over } \\
5000 \\
\text { Acres } \\
\mathrm{N}=25^{1}\end{array}$ & $\begin{array}{c}\text { Estimated } \\
\text { \% Total } \\
\text { Acres } \\
\text { Wtd. } \\
\text { Sample }^{2}\end{array}$ \\
\hline Sells products from land ${ }^{3}$ & $27.8^{\mathrm{a}}$ & $83.0^{b}$ & $100.0^{c}$ & 72.7 \\
\hline Produces livestock & $27.8^{\mathrm{a}}$ & $75.0^{b}$ & $96.0^{\circ}$ & 65.4 \\
\hline Livestock graze property & $45.7^{\mathrm{a}}$ & $83.0^{b}$ & $100.0^{c}$ & 77.6 \\
\hline Seasonally grazed & $19.4^{\mathrm{a}}$ & $53.8^{\mathrm{b}}$ & $58.3^{\mathrm{b}}$ & 48.9 \\
\hline Sells firewood & $5.6^{\mathrm{a}}$ & $22.6^{\mathrm{b}}$ & $40.0^{b}$ & 28.3 \\
\hline Fee-paying guests & $2.8^{\mathrm{a}}$ & $7.7^{\mathrm{n}}$ & $24.0^{\mathrm{b}}$ & 15.4 \\
\hline $\begin{array}{l}\text { Land in Timber Production } \\
\text { Zone }\end{array}$ & $0.0^{2}$ & $49^{\mathrm{a}}$ & $130^{\mathrm{a}}$ & 9.8 \\
\hline Land in Williamson Act & $8.0^{\mathrm{a}}$ & $61.2^{b}$ & $69.7^{b}$ & 52.9 \\
\hline Improves wildlife habitat & $19.5^{\mathrm{a}}$ & $40.4^{b}$ & $56.0^{\mathrm{b}}$ & 40.3 \\
\hline $\begin{array}{l}\text { Less than } 5 \text { miles to } \\
\text { subdivision }\end{array}$ & $50.0^{\mathrm{a}}$ & $51.0^{\mathrm{a}}$ & $56.0^{a}$ & 56.1 \\
\hline Subdivided in last 5 years & $11.1^{\mathrm{n}}$ & $11.5^{\mathrm{a}}$ & $4.0^{\mathrm{a}}$ & 9.1 \\
\hline Thins oaks & $30.5^{\mathrm{a}}$ & $30.7^{\mathrm{a}}$ & $52.0^{\circ}$ & 41.4 \\
\hline Cuts living oaks & $61.1^{\mathrm{a}}$ & $75.5^{b}$ & $84.0^{\mathrm{b}}$ & 77.2 \\
\hline $\begin{array}{l}\text { Important reasons to cut } \\
\text { oaks are: }\end{array}$ & & & & \\
\hline $\begin{array}{l}\text { Cutting dead or diseased } \\
\text { oaks }\end{array}$ & $100^{\mathrm{a}}$ & $87.5^{\mathrm{sc}}$ & $72.7^{\mathrm{bc}}$ & $\mathbf{n} / \mathbf{a}$ \\
\hline Firewood income & $8.0^{\mathrm{a}}$ & $10.7^{a}$ & $30.0^{\mathrm{a}}$ & $\mathbf{n} / \mathbf{a}$ \\
\hline $\begin{array}{l}\text { Increasing forage } \\
\text { production }\end{array}$ & $20.0^{\mathrm{a}}$ & $45.8^{\mathrm{b}}$ & $61.9^{c}$ & $\mathrm{n} / \mathrm{a}$ \\
\hline Increasing waterflow & $12.0^{\mathrm{a}}$ & $14.6^{\mathrm{a}}$ & $47.6^{\mathrm{b}}$ & $\mathrm{n} / \mathrm{a}$ \\
\hline Clearing for development & $24.0^{n}$ & $25.0^{\mathrm{n}}$ & $14.3^{\mathrm{a}}$ & $\mathbf{n} / \mathbf{a}$ \\
\hline Improving access & $28.0^{\mathrm{a}}$ & $40.4^{\mathrm{ab}}$ & $57.1^{\mathrm{b}}$ & $\mathbf{n} / \mathbf{a}$ \\
\hline
\end{tabular}

iN varies slightly with each question.

2Estimated percent of California oak woodland acres owned by landowners with the above characteristics or using the practices above on some or all of their land. ${ }^{3}$ Within rows, values without a common superscript are significantly different at $p<.05$, as determined by Chi-square analysis.

\section{Table 4. Landowner attitudes and values.}

\begin{tabular}{|c|c|c|c|}
\hline & $\begin{array}{c}\% \text { Owners } \\
\text { Under } \\
200 \text { Acres } \\
\mathrm{N}=361\end{array}$ & $\begin{array}{c}\% \text { Owners } \\
200-5000 \\
\text { Acres } \\
\mathrm{N}=53^{1}\end{array}$ & $\begin{array}{c}\% \text { Owners } \\
\text { Over } \\
5000 \text { Acres } \\
N=251\end{array}$ \\
\hline $\begin{array}{l}\text { Respondents agree that: } \\
\text { State regulation means a loss of liberties and freedom }{ }^{2} \\
\text { Regulation leads to socialism } \\
\text { Aerial herbicide spraying is ok at the landowner's discretion } \\
\text { Oaks are being lost in California } \\
\text { Should regulate California oak use } \\
\text { The state consults adequately with citizens before regulating } \\
\text { resources }\end{array}$ & $\begin{array}{l}52.9^{\mathrm{a}} \\
38.2^{\mathrm{a}} \\
29.4^{\mathrm{a}} \\
61.3^{\mathrm{a}} \\
35.3^{\mathrm{a}} \\
17.6^{\mathrm{a}}\end{array}$ & $\begin{array}{l}65.3^{\mathrm{ab}} \\
50.0^{\mathrm{a}} \\
61.5^{\mathrm{b}} \\
51.0^{\mathrm{b}} \\
31.4^{\mathrm{a}} \\
10.0^{\mathrm{a}}\end{array}$ & $\begin{array}{c}79.2^{\mathrm{b}} \\
58.3^{\mathrm{a}} \\
75.0^{\mathrm{b}} \\
20.8^{\mathrm{c}} \\
8.0^{\mathrm{b}} \\
4.2^{\mathrm{a}}\end{array}$ \\
\hline $\begin{array}{l}\text { The respondent values oaks: } \\
\text { for property value } \\
\text { for shade } \\
\text { for erosion control } \\
\text { as wildlife habitat } \\
\text { for their natural beauty } \\
\text { as fuelwood } \\
\text { for more forage underneath }\end{array}$ & $\begin{array}{l}64.7^{\mathrm{a}} \\
71.4^{\mathrm{a}} \\
64.7^{\mathrm{a}} \\
80.0^{\mathrm{a}} \\
88.0^{\mathrm{a}} \\
55.9^{\mathrm{a}} \\
38.2^{\mathrm{a}}\end{array}$ & $\begin{array}{l}63.5^{\mathrm{a}} \\
82.4^{\mathrm{a}} \\
63.5^{\mathrm{a}} \\
85.7^{\mathrm{a}} \\
83.0^{\mathrm{a}} \\
71.2^{\mathrm{a}} \\
32.7^{\mathrm{a}}\end{array}$ & $\begin{array}{l}37.5^{\mathrm{b}} \\
72.0^{\mathrm{a}} \\
37.5^{\mathrm{b}} \\
66.7^{\mathrm{a}} \\
83.3^{\mathrm{a}} \\
58.3^{\mathrm{a}} \\
16.7^{\mathrm{a}}\end{array}$ \\
\hline $\begin{array}{l}\text { Moved to oak woodland because of: } \\
\text { natural beauty } \\
\text { job opportunities } \\
\text { to get away from city } \\
\text { to have a different lifestyle } \\
\text { for the recreation } \\
\text { for the lower cost of living } \\
\text { because of a family business or property }\end{array}$ & $\begin{array}{l}80.0^{\mathrm{a}} \\
23.2^{\mathrm{a}} \\
80.0^{\mathrm{a}} \\
73.3^{\mathrm{a}} \\
60.0^{\mathrm{a}} \\
33.3^{\mathrm{a}} \\
30.0^{\mathrm{a}}\end{array}$ & $\begin{array}{l}70.2^{\mathrm{ab}} \\
40.4^{\mathrm{a}} \\
68.1^{\mathrm{a}} \\
51.1^{\mathrm{ab}} \\
59.6^{\mathrm{a}} \\
34.0^{\mathrm{a}} \\
74.5^{\mathrm{b}}\end{array}$ & $\begin{array}{r}47.6^{b} \\
25.0^{\mathrm{a}} \\
35.0^{\mathrm{b}} \\
30.0^{\mathrm{b}} \\
25.0^{\mathrm{b}} \\
5.0^{\mathrm{b}} \\
85.0^{\mathrm{b}}\end{array}$ \\
\hline
\end{tabular}

IN varies slightly with each question.

2Within rows, values without a common superscript are significantly different at $p<.05$, as determined by Chi-square analysis. 
were determined by natural breaks in the data set for the variable "ownership size." The Chi-square statistic was then used to determine significance.

Second, in order to estimate the amount of oak woodland potentially affected by certain landowner management practices or demographic characteristics, responses were weighted in inverse proportion to size of ownership. This mathematical adjustment, described in Wensel (1983), adjusts the distribution of ownership sizes in the sample to make it comparable to that of ownerships in the oak woodland as a whole, so estimates of the proportion of total oak woodland owned by landowners who claim certain practices and particular demographic characteristics can be developed. For example, after weighting, if $30 \%$ of the land in the sample is owned by landowners who carry out a certain practice, it can be estimated that $30 \%$ of all oak woodland is owned by landowners who carry out this practice. Analyses using the weighted sample are identified in the tables.

\section{Results}

Large parcel owners owned most of the land in the survey sample (Table 1). However, weighting the responses suggests that landowners with more than 5,000 acres and those with less than 200 acres each own about $30 \%$ of the land. The weighted estimate also reveals that the vast majority of oak woodland landowners own parcels of less than 200 acres.

\section{Demographics and Ownership}

Most demographic differences were not significant, although education level decreased and age increased with property size (Table 2). Landowners with more than 5,000 acres were significantly more likely to make more than $\$ 75,000$ per year, to belong to livestock association or farm bureau, to have had the land in the family for 21 years or more, and to report ranching as their major source of income.

There is a trend to higher absentee ownership among smaller ownerships (Table 2). The vast majority of those with fewer than 200 acres obtain their livelihood by nonagricultural means such as investments, retirement pensions, wages, or businesses, as do the majority of landowners with holdings under 5,000 acres.

Estimates based on weighted sample indicate that almost $23 \%$ of oak woodland is owned by absentee landowners, and more than one-third of the oak woodland is owned by landowners who have a main source of income other than farming, ranching, or timber.

Fewer than a third of the landowners in any category belonged to a wildlife or environmental group, or had made contact with any advisory service about oaks within the last 5 years.

\section{Land Use}

Differences in land use among the 3 categories were quite significant (Table 3). In general, the larger the ownership category, the more likely the land was used for economic purposes. Livestock production was the most common land use reported by owners of more than 200 acres. These owners were more likely to have their land in a Timber Production Zone or registered under the Willaimson Act ${ }^{1}$, to sell firewood, to believe firewood income to be important, to have fee-paying guests, and to improve wildlife habitat. One indication of the pressure of urbanization on oak woodlands was the fact that half of landowners in all 3 size categories were less than 5 miles from the nearest subdivision.

More than two-thirds of oak woodland owners in all categories removed some oaks; nearly all of them removed living as well as

\footnotetext{
${ }^{1}$ Both Timber Production Zone (an element of the 1975 Forest Taxation Reform Act) and Williamson Act (California Land Conservation Act of 1965) landowners are taxed at a lower property tax rate in exchange for maintaining land in timber or agricultural production. In 1985 , about 5.5 million acres were zoned as Timber Production zones, and 15.2 million acres were designated in Williamson Act. In both cases, contracts are 10 years long and self-renewing.
}

dead oaks. Thinning oaks was carried out by more than $30 \%$ of property owners in all categories. The primary reasons given for cutting oaks were to increase forage production, waterflow, and access. As expected from the frequency of cutting, all reasons were more often important to those with more than 5,000 acres. Clearing land for development was the exception, showing no significant difference among ownership categories.

The weighted estimates demonstrate that because large property owners own a large proportion of the acres, their behavior affects a large part of the oak woodland. More than $65 \%$ of the oak woodland is owned by those who produce livestock; another $12 \%$ by those allowing others to graze stock on their land (Table 3). Almost a tenth of the oak woodland is owned by those reporting that they have subdivided all or part of their property within the last 5 years. Landowners who thin oaks own about $41 \%$ of the oak woodland. Thinning of oaks was also the oak management practice most likely to be undertaken more than once, with more than a quarter of all respondents reporting that they thinned some oaks on their property as a matter of routine practice.

\section{Attitudes toward Regulation and the Oak Woodland}

More than half of the landowners in any category were opposed to any regulation of land or resource use (Table 4). However, those with smaller properties were significantly more likely to agree that oaks were being lost in California, and that oak use should be regulated. Landowners with more than 200 acres, on the other hand, supported the right of a landowner to act independently to the extent that a majority agreed that the use of aerial herbicides and pesticides should be completely at the discretion of the landowner, without any regulatory interference.

Owners of small and large parcels sought different values in the oak woodland, most dramatically revealed in reasons they gave for living there (Table 4). Eighty percent of owners of less than 200 acres reported that they felt the natural beauty of the oak woodland was important in influencing them to live there. They were more likely than owners of large parcels to report that a different lifestyle, getting away from the city, and recreation opportunities had a strong effect on their decision to live in the oak woodland. In contrast, more than $80 \%$ of the owners of more than 5,000 acres reported that a family business or property was an important reason why they lived in the oak woodland. A common comment volunteered by the respondents in this group was, "I was born here." Nonetheless, nearly half of these landowners found the natural beauty of the oak woodland an important reason to live there.

A majority of landowners in every category reported that shade, erosion control, wildlife habitat, natural beauty, and fuelwood were important reasons they liked to have oaks on their property (Table 4). However, property owners with more than 5,000 acres were significantly less likely to value oaks for their contribution to property values than those with smaller properties. Most landowners apparently do not believe that there is more forage under oaks, although research has indicated that this may sometimes be the case (Holland 1980, Holland and Morton 1980, McClaran and Bartolome 1987).

\section{Discussion and Conclusions}

More than three-fourths of California's oak woodland is grazed by livestock, although grazing or livestock sales may not constitute the owner's major source of income. Production-related landowner objectives of increasing forage, access, and waterflow are critical components of landowner decisions about how to manage land on the majority of the oak woodland, and those objectives must be carefully considered in the development of education programs and policy. 
The traditional clientele of advisory agencies is well-represented among the owners of more than 200 acres. As property size increases, so does the likelihood that landowners are livestock producers, have their land registered under the Williamson Act, sell firewood, and spend all or part of the year on their land. Most landowners with more than 200 acres belong to livestock association or farm bureau, have kept the land in their family for longer than 20 years, and live in the oak woodland because it provides a livelihood. They manage for production-related objectives, but also value having oaks on their property for other reasons, including their beauty and as wildlife habitat. These landowners generally disagree that oaks are being lost in California and agree that regulation leads to a loss of essential liberties and freedoms.

A new type of landowner is becoming important on private California hardwood rangelands. These residents own small parcels, but they have reached numbers sufficient that owners of less than 200 acres already own more than a quarter of the oak woodland. Less than a third of these landowners sell any kind of product, including firewood, from their land, and the majority report that most of their income is earned elsewhere. More of these landowners are absentee, and fewer cut living oaks. Less than half of these landowners have lived in the same county for more than 20 years. They most often report natural beauty as the reason for living in the oak woodland. They too value oaks for many reasons, including beauty, wildlife habitat, shade, and erosion control. Fewer of these landowners believe that state and federal regulations lead to a loss of essential liberties and freedoms and most believe that oaks are being lost in California. This group is difficult to reach with traditional education programs.

Research education programs and policy must be directed at groups with differing skills and access to differing management and labor resources. All owners valued oaks for assorted yet similar reasons, but owners of larger properties will respond best to programs that protect and enhance the livelihood they earn by using their oak woodland property. Although those whose livelihood depends on the land, the "traditional clientele," are concerned about the impacts of oaks on the livelihood, they gave compelling reasons for wanting oaks on their property. Education programs offering management strategies that maintain vigorous oak stands, while contributing to (or at least not compromising) landowner income, should be quite attractive. Research projects that develop economical practices and technologies for maintaining and regenerating oaks, clarify the role of oaks in forage production, and develop optimization models for maintaining oaks as part of an income-producing land management strategy will contribute most to an education effort for these landowners.

More than $80 \%$ of landowners with greater than 200 acres sold products produced from their land, yet better than half reported a majority of their income from other sources. Whether or not this is an increasing trend is unknown. It is an indication, however, that for these landowners, considerations other than just increasing income from livestock production are important. These landowners place high value on oaks for shade, wildlife habitat, and natural beauty. The interest of these landowners in these values, and in good stewardship as a way of life, should not be neglected in education programs.

Owners of smaller properties will respond best to programs and regulations that they believe will contribute to bettering the quality of life they seek by living in the oak woodland. More intensive management strategies-such as how to treat diseased treeswould appeal to these new types of owners, as their sources of income are not affected by land management costs. More than $80 \%$ of those with less than 200 acres valued oaks as wildlife habitat, yet fewer than $20 \%$ reported improving wildlife habitat on their property. Here, lack of knowledge could be the limiting factor. Only a few of these landowners reported contact with any advisory service bout oaks. Small ownerships are on the increase. Between 1970 and 1980 the non-metropolitan population of California increased $42 \%$ compared to a growth rate of $15 \%$ in the previous decade (Hope and Blakely 1986). With this group has come increased demand for housing, resulting in the conversion of farms, forests, and rangelands for housing sites.

Subdivisions and other developments are changing the character of the oak woodland. Not only is land removed from range production, but resources are affected indirectly. The expansion of residential areas creates a better fuelwood market. It also creates conflicts, as lifestyles and values clash. Suburban oak woodland residents may feel that livestock detract from the natural beauty they seek in the oak woodland. Owners of large properties may find that the newer, suburban, oak woodland residents interfere with livestock production-related activities. Suburban dogs harass livestock. Vandalism of buildings and equipment may increase.

The evidence that oaks are an important reason why new residents move to the oak woodland can be used to encourage developers and planners to maintain stands of oaks whenever possible. Education and advisory efforts aimed toward landscape architects, engineers, land use planners, and developers would be one way to help mitigate the loss of oaks to development. Zoning, land use planning, regulation of harvest, and incentive programs are other possibilities. Of the owners of less than 200 acres, more than half think oaks are being lost and a third think oak use should be regulated-and this group is numerically and proportionately on the increase.

What the urban resident sees as the legitimate right to regulate and to affect the management of vast expanses of wilderness may appear to the rancher to be interference by outsiders in his or her own backyard. On the other hand, although most of the landowners surveyed feel that in general regulations are undesirable, the data indicate that many owners of larger properties are taking advantage of regulatory devices like the Williamson Act. (Owners of small properties generally do not qualify for Williamson Act designation).

The increasing proportion of small landowners means a greater diversity of lifestyles, management practices, and goals, and a more complex setting for landowner education and state policy development. Although owners of smaller properties are more sympathetic to the idea that oak woodlands need protection, the potential uses of the resource by wildlife, recreationists, and as open space are limited with small ownerships. The actions of the few who own the greater portion of the oak woodland, in contrast, are more predictable, in that they are closely tied to the productive capacity of the land. These landowners are the stewards of the vast acreages of open woodland that most Californians think of as oak woodland. Education programs, policies, and research that enhance the value of oaks for this group, and that help this group to succeed, will be most effective in preserving these open woodlands.

Owners of large and small properties, ranchers, and urbanites, share the oak woodlands of California. They are not independent. Changes that affect one inevitably will affect the other. Policy and education programs that address only one group, or only one cause of loss of oak woodland, will not succeed in stopping its decline in California. And although California is one of the nation's most rapidly growing states, the lessons learned here apply to many rural areas. The decade from 1970 to 1980 witnessed an unparalleled growth in non-metropolitan population, exceeding the national population growth rate (Long and DeAre 1982). A changing society challenges range managers to go beyond simple assumptions about the people who own, manage, and use rangelands. Carefully applied, modern survey research technique is one tool range managers can use to meet this challenge. 


\section{Literature Cited}

Bolsinger, C. 1988. The hardwoods of California's timberlands, woodlands, and savannas. U.S. Forest Serv., Pacific Northwest Forest and Range Exp. Sta., PNW-RB-148. Portland, Ore.

Burcham, L.T. 1982. California range land: An historico-ecological study of the range resource of California. Center for Archeol. Res. at Davis. Pub. 7, Univ. California, Davis.

Dillman, D.A. 1975. Mail and telephone surveys: The total method. Wiley and Sons, New York.

Ewing, R.A., N. Tosta, R. Tuazon, L. Huntsinger, R. Marose, K. Nielson, R. Motroni, and S. Turan. 1988. Growing conflict over changing uses. California Dep. Forestry and Fire Protection. Anchor Press, Sacramento, Calif.

Farquhar, F.P. (ed). 1966. Up and down in California in 1860-1864: The journal of William H. Brewer. Univ. California Press, Berkeley.

Fortmann, L.P., and L. Huntsinger. 1987. Managing California's oak woodlands: a sociological study of owners. In:T. Plumb and N. Pillsbury (tech. coords.). Symposium on multiple-use management of California's hardwood resources. November 12-14, Cal Poly State University, San Luis Obispo, Calif. Gen. Tech. Rep., PSW-100 p. 379-384. USDAForest Serv., Pac. Southw. Forest and Range Exp. Sta., Berkeley, Calif.

Giordano, G. 1978. Les plantations d'arbes a croissance rapide comme integration de l'agriculture de la plaine. In: La foret dans le monde: ses roles dans la view ruralc. March 1-3, Paris, France. Colloque International CENECA.

Green, J.L., and K.A. Blatner. 1986. Identifying woodland owner characteristics associated with timber management. Forest Sci. 321:135-146.

Griffin, J.R. 1978. Oak woodland. p. 383-416. In: Barbour, M.G. and J. Major (eds.). Terrestrial vegetation of California. Univ. California, Davis. John Wiley and Sons, New York.

Grigsby, T.L. 1976. Buckaroo ranchers: sociocultural factors related to economic performance among range livestock operators of southeastern Oregon. Ph.D. Diss. Univ. Oregon, Eugene.

Guillard, J. 1982. Influence of the size of forests on their management. Seminiar: Institutional and economic implications of the size of forest holdings on their management. European Forestry Commission, 20th Session, Innsbruck, Austria. Food and Agr. Organiz. Doc. \#83.31713. Fo: EFC/82/13.

Healy, R.G. 1985. How much urban impact on the South's farm and forest lands? Rural Development Perspectives. (October):27-30.

Healy, R.G., and J.L. Short. 1981. The market for rural land: trends, issues, policies. Conserv. Found., Washington, D.C.

Heffernan, W.D., and G.P. Green. 1986. Farm size and soil loss: prospects for a sustainable agriculture. Rural Sociology 51:31-42.

Holland, V.L. 1980. Effect of blue oak on rangeland forage production in central California. In:T.R. Plumb (tech. coord.). Ecology, Management, and Utilization of California Oaks. June 26-28, Claremont, Calif. Gen. Tech. Rep. PSW-44. USDA-Forest Serv. Pac. Southw. Forest and Range Exp. Sta. Berkeley, Calif.

Holland, V.L., and J. Morton. 1980. Effect of blue oak on nutritional quality of rangeland forage in central California, p. 319-322. In: T.R. Plumb (tech. coord.). Ecology, Management, and Utilization of California Oaks. June 26-28, Claremont, Calif. Gen. Tech. Rep. PSW-44. USDA-Forest Serv., Pac. Southw. Forest and Range Exp. Sta., Berkeley, Calif.

Hope, J., and E. Blakely. 1986. A rural development agenda for California: recommendations from the 1985 regional conferences on natural resources and rural economic development. Sen. Off. of Res., Sacramento, Calif.
, J.W. 1966. A modified Koeppen classification of California climates according to recent data. The Calif. Geog. 7:1-12.

Kay, B.L., and O.A. Leonard. 1980. Effect of blue oak removal herbaceous forage production in the North Sierra Foothills. p. 323-328. In. T.R. Plumb (tech. coord.). Ecology, Management, and Utilization of California Oaks. June 26-28, Claremont, Calif. Gen. Tech. Rep. PSW-44. USDA-Forest Serv., Pac. Southw. Forest and Range Exp. Sta., Berkeley, Calif.

Leveque, F. 1984. Les bois paysans en Dordogne. Revue Forestiere Francaise. XXXVI:485-496.

Long, L., and D. DeAre. 1982. Repopulating the countryside: a 1980 census trend. Sci. 217:1111-1116.

Martin, W.E., and G.L. Jefferies. 1966. Relating ranch prices and grazing permit values to ranch productivity. J. Farm Econ. (Amer. J. Agr. Econ.) 48:233-242.

Mayer, K.E., P.C. Passof, C. Bolsinger, W.W.J. Grenfell, and H. Slack. 1986. Status of the hardwood resource of California: a report to the Board of Forestry. California Dep. Forest. and Fire Protect., Sacramento, Calif.

McClaran, M.P., and J.W. Bartolome. 1987. Geographic variation in the affect of blue oak canopy on herbaceous production and consumption. California Dep. Forest. and Fire Protect., Sacramento, Calif.

McClaran, M.P., and J.W. Bartolome. 1985. The importance of oaks to ranchers in the California Foothill Woodland. Rangelands 7:158-161.

Muick, P.C., and Bartolome, J.W. 1987. An assessment of natural regeneration of oaks in California. California Dep. Forest. and Fire Protect., Sacramento, Calif.

Ostrum, E. 1985. Issues of definition and theory: some conclusions. Proc. Confer. on Common Property Resource Management. April 21-26, Annapolis, Md. p. 599-613. Academy Press, Washington, D.C.

Romm, J., C. Washburn, R.N. Tuazon, and J. Bendix. 1985. Forest owners and the state: California policy for growing forests on non-idustrial land. Univ. California Dep. Forest. and Resour. Manage., Bcrkeley.

Shanks, B. 1978. Social and institutional barriers to rangeland management innovations. p. 92-94. In: D.N. Hyder (ed.). Proc. First Int. Rangeland Congr. August 14-18, 1978. Denver, Colo. Soc. Range Manage.

Smith, A.H., and W.E. Martin. May 1972. Socioeconomic behavior of cattle ranchers, with implications for rural community development in the West. Amer. J. Agr. Econ. 54:217-255.

South, D.R., T. Hansbrough, and A.L. Bertrand. 1965. Factors related to the adoption of woodland management practices. Louisiana State Univ. and Agr. and Mech. Coll. Agr. Exp. Sta., Bull. 603, Baton Rouge.

Sudworth, G.B. 1908. Forest trees of the Pacific slope. U.S. Forest Serv., Government Printing Off., Washington, D.C.

Thompson, R.P., and J.G. Jones. 1981. Classifying nonindustrial forestland by tract size. J. Forest. 79:288-291.

USDA-Forest Serv. 1981. Resources evaluation field instructions for California, 1981-1984. Pac. Northw. Forest and Range Exp. Sta., Portland, Ore.

Wensel, L.C. 1983. Estimators for use in California forestland ownership studies. Univ. California Dep. Forest and Resour. Manage., Biometrics Note \#8. Berkeley, Calif.

Young, M.D. 1985. The influence of farm size on vegetation condition in an arid area. J. Environ. Manage. 21:193-203. 